\title{
The Free Movement of Inactive Citizens in THE EU - A CHALLENGE FOR THE EUROPEAN WELFARE STATE?
}

\author{
WOLFGANG OCHEL
}

CESIFO WORKING PAPER No. 1930

CATEGORY 3: SOCIAL PROTECTION

FEBRUARY 2007

An electronic version of the paper may be downloaded

- from the SSRN website:

- from the RePEc website:

wWw.SSRN.com

- from the CESifo website: 


\title{
ThE FREE MOVEMENT OF INACTIVE CITIZENS IN THE EU - A CHALLENGE FOR THE EUROPEAN WELFARE STATE?
}

\begin{abstract}
The EU Directive on Free Movement of 2004 extended free movement within the EU to Union citizens who are inactive and gave them access to the welfare benefits of host countries. The paper examines the extent to which these measures provoke migration to those countries with the highest levels of welfare benefits. The paper concludes that migration is limited by the requirement of considerable financial assets in order to bridge a waiting period of five years as well as negative financial incentives. On the other hand, migration is attractive for those working in the informal sector of host countries.
\end{abstract}

JEL Code: I38, J60, J61.

Keywords: EU Free Movement Directive, welfare tourism, inactive citizens.

\author{
Wolfgang Ochel \\ Ifo Institute for Economic Research \\ at the University of Munich \\ Poschingerstr. 5 \\ 81679 Munich \\ Germany \\ ochel@ifo.de
}

Comments and support by Wolfgang Meister and Martin Werding are gratefully acknowledged. 


\section{The Free Movement of Inactive Citizens in the EU - A Challenge for the European Welfare State?}

\section{Introduction}

The EU Directive on Free Movement and Residence of 2004 (Directive) extended free movement within the European Union (EU) to Union citizens who are inactive (non-gainfully employed). At the same time, this group of persons has been given access to the welfare benefits of host countries. This poses the question, to what extent these measures provoke migration to those countries with the highest levels of welfare benefits. Since the Directive was not implemented in national laws and regulations until 2006, there is no basis for formulating an answer to this question based on an expost analysis of migration flows. Rather, the approach pursued here is to quantify the incentives to migrate based on a number of model cases. In this paper, Poland is taken as the country of origin and Germany as the host country.

The paper is structured as follows: section 2 deals with the rights of Union citizens to move and reside freely within the EU. Section 3's topic is access of inactive citizens to the systems of social assistance in the host countries. In section 4 the scope for welfare tourism is discussed. Sections 5 to 7 present calculations of the financial incentives to migrate in selected cases of legal and illegal migration. Section 8 contains a summary and an evaluation of the results.

\section{Union citizens' right to move and reside freely in the $\mathrm{EU}$}

The right to free movement and residence in the EU has been considerably extended since its founding in 1957. At its inception, free movement was conceived of as an economic freedom. Workers were guaranteed freedom of movement and self-employed were guaranteed freedom of establishment. However, those not gainfully employed had no right to establish residence outside their own country.

Since the beginning of the 1990 s, the right to stay in another member country than one's own is no longer tied to participation in the economy. This was expressed clearly in the Directives on Free Movement and Residence of the early 1990s which provided, under certain conditions, a right of residence for students, retired persons and other inactive persons. In 1993, the Maastricht Treaty explicitly provided (in Article 18) that every Union citizen, whether gainfully employed or not, has the right to move and reside freely within the territory of Member States. The implementing regulations and the relevant decisions of the European Court were developed further and summarised in Directive 2004/38/EC.

Member States were required to implement the Directive in their national law by 30 April 2006. In Germany, the implementing instrument is the Law on the General Free Movement of Union Citizens (Law on Free Movement of the EU - Art. 2 of the Law on Immigration) which went into force on 1 January 2005. The implementation of the Directive is up till now not comprehensive. It was 
not possible to take into account all the details of the Directive by that date. ${ }^{1}$ The modifications of the Law on Free Movement of the EU will eliminate this deficit by the beginning of 2007 (Gross 2006).

The Directive provides that with respect to Union citizens the residence permit is abolished; previously it was necessary to submit an application for this permit. Instead, in a simplified procedure a certification of the right of residence will be issued. The Directive provides for graduated regulations governing residence: no conditions are imposed on a Union citizen and his family members for residence in another member country other than valid identity papers for a period of up to three months. For a stay of between four to sixty months, a residence certificate is required. In order to obtain it, the Union citizen must establish his residence in Germany and register with the relevant authorities. At the end of five years of uninterrupted legal residence ${ }^{2}$ the Union citizen is entitled unconditionally to permanent residence.

Granting a residence certificate for inactive Union citizens in the period between the fourth and the sixtieth month requires that they should have means of subsistence sufficient for the entire stay and that they should have adequate health insurance. These conditions are designed to ensure that social assistance will not be applied for. The provisional instructions issued by the German Federal Ministry of the Interior in 2004 laid down that the means of subsistence include all legal forms of income and wealth in money or in money equivalents and other resources of the person in question. ${ }^{3}$ What can be considered as adequate depends on the circumstances of the individual case. Health insurance coverage is considered to be adequate when it is - in the case of Germany - equivalent to statutory health insurance. Since access to statutory health insurance in Germany is subject to restrictive conditions (see Box 1), as a rule, foreigners from other EU countries will have to obtain health insurance from private insurers.

When a Union citizen registers in Germany, the registration office proceeds on the assumption that the requirements for residence are fulfilled if the person registering declares that they are. Unless there are prima facie grounds for doubt, no enquiries are instigated before issuing the certification requested. And in the ensuing five years no check on the fulfilment of the conditions for permanent residency is carried out unless the Union citizen applies for welfare benefits. In such a case the authority responsible for foreigners, after having been informed by the Social Assistance Office, can examine whether the requirements for residence continue to be fulfilled. The required amount of means of subsistence should not exceed the threshold defined for social assistance for nationals. At the same time, no uniform amount for means of subsistence should be fixed. On the contrary, re-

\footnotetext{
At the end of 2004 the German Federal Ministry of the Interior issued "provisional" instructions on the application of the Law on Free Movement of the EU.

2 Temporary absence of up to six months in a year does not affect the continuity of residence.

3 Included amongst the other resources are payments for support by family members or third persons, scholarships, grants and allowances for educational purposes, unemployment benefits, old-age benefits and other public payments based on previous contributions.
} 
gional differences and the personal situation of the applicant must be taken into account. Merely claiming social assistance is not sufficient grounds for expulsion, but only laying a claim to excessively high benefits. What is excessive is, however, left unclear.

\section{Box 1 Health insurance available for an inactive Pole residing in Germany}

A Voluntary coverage in Germany's statutory health insurance

Requirements according to Art.9 of the Social Code V:

- Absolved from the insurance requirement of Polish Social Insurance (ZUS)

- During five years before being absolved, at least 24 months, or immediately before being absolved uninterruptedly at least 12 months insured in Poland's National Health Fund

(Narodowy Fundusz Zrowia - NFZ)

Additional conditions imposed by the German Federal Ministry for Labour and Social Affairs:

- Prior insurance coverage for at least one day in Germany.

B Coverage by a private provider of health insurance in Germany.

C No possibility exists to continue insurance coverage in Poland if residence is changed to Germany.

Source: Compilation by CESifo.

Since 1 May 2004 the right of free movement within the EU also applies to the non-gainfully employed persons from the new Central and East European member countries. They enjoy the same unlimited freedom of movement as established self-employed persons. In this respect, the nongainfully employed are distinguished from the workers of these countries, for whom the EU member countries can limit access to their labour markets for a period of seven years (i.e. until 2011). At the beginning of November 2006 Belgium, Denmark, Germany, France, Luxembourg, the Netherlands, and Austria continue to maintain this restriction, whilst the remaining eight countries of EU15 have introduced unrestricted freedom of movement.

\section{Access of inactive persons to the systems of social assistance of host countries}

As long as inactive EU citizens had no right to take up residence in other member countries, they could not claim welfare benefits in those countries. The extension of the right of free movement to them, however, has changed the situation radically (see Box 2):

- During a stay of less than three months, inactive Union citizens are not entitled to social assistance. Parity with citizens of the host country is not provided. ${ }^{4}$

- During a stay lasting between four and sixty months, Union citizens are as a matter of principle entitled to welfare benefits, although the requirement of sufficient resources and adequate health insurance coverage is designed to ensure that this entitlement remains theoretical. In

4 Nonetheless, Article 14 (1) of the Directive does not fully exclude claiming welfare benefits. 
case the resources are exhausted sooner than expected or when health insurance coverage is not adequate, then the Social Assistance Offices grant benefits even though the conditions for residence are not fulfilled. If the host country wants to avoid this, the Union citizen's stay must be brought to an end (Sander 2005, 1016). As set out above, this involves an examination by the authority responsible for foreigners as to whether the claims to welfare were inappropriate.

- After a stay of five years, the Union citizen is entitled to the same welfare benefits as those the host country provides to its own nationals.

\section{Box 2 Entitlements of inactive Union citizens to welfare benefits of the host country}

\begin{tabular}{|l|l|}
\hline Phase of stay & Rule \\
\hline $\begin{array}{l}\text { 1-3 months } \\
\text { 4-60 months }\end{array}$ & $\begin{array}{l}\text { No entitlement. } \\
\text { As a matter of principle, an entitlement to welfare benefits exists, but the requirement that } \\
\text { the Union citizen has sufficient resources and health insurance coverage is designed to } \\
\text { ensure that in practical terms this entitlement will not become relevant. } \\
\text { In the event that the citizen becomes needy, welfare benefits will be provided; at the same } \\
\text { time, the conditions for continued residence will be examined and expulsion may possibly } \\
\text { be ordered. }\end{array}$ \\
\hline $\begin{array}{l}\text { Five years or } \\
\text { longer }\end{array}$ & $\begin{array}{l}\text { Entitled to welfare benefits. } \\
\text { Union citizens are placed on an equal basis with citizens of the host country. }\end{array}$ \\
\hline
\end{tabular}

Source: Compilation by CESifo.

On the one hand, the Directive grants inactive persons an entitlement to welfare benefits, on the other hand, the Directive makes access to the welfare systems of the host countries relatively difficult. Granting access to foreign welfare benefits serves the goal of strengthening European integration. Access implies that nationals of an EU country will give assistance to EU citizens from other countries in case of need, even when they are not gainfully employed. In exercising social solidarity within the EU, citizens' feeling of belonging together should be strengthened and this in turn should promote the political union (Schierup, Hansen and Castles 2006, 5). But the Directive was not only inspired by the superordinate goals of political integration, but also by decisions handed down by the European Court of Justice. Based on the idea of Union citizenship established in Maastricht (Art. 18 EC) and the prohibition of discrimination based on nationality (Art. 12 EC) laid down there, the Court concludes that inactive Union citizens are entitled to welfare benefits outside their own country. The argumentation leading to this conclusion seems, however, to be open to doubt, since the discussion leading up to the passage of Art. 18 as well as the text of the Article does indeed provide for the extension of freedom of movement to include all Union citizens, but it does not specifically lay down that those enjoying free movement are also entitled to welfare benefits (Sander 2005, 1016-17). In appealing to the prohibition against discrimination insufficient attention was given to the question whether - from a legal point of view - the area of application of the EC treaty is so defined that all Union citizens have a comprehensive right to be treated as nationals 
(Niemann 2004, 948) and whether - from an economic point of view - the prohibition of discrimination does not prevent the application of sensible migratory and social policy measures (CESifo, EEAG, chapter 4).

The justification for making access of non-gainfully employed to welfare benefits financed by taxes difficult is related to the fact that the non-gainfully employed - in distinction to the gainfully employed - as a rule have not paid taxes in the host country. They have not contributed to the prosperity of the host country and for that reason, they should not be entitled in case of need to social benefits (Tomuschat 2000). Non-gainfully employed Union citizens are dependent on the solidarity of citizens in the host country. Their tax payments are used in part to provide for needy Unions citizens from other EU countries, at least as long as there is no financial compensation scheme within the EU. It is extremely questionable whether the required solidarity exists in the EU at the present time. The development of a European Social Union has in any case up till now shown scarcely any progress (Hailbronner 2005 and 2006).

Free access to welfare benefits could, furthermore, provoke migration of non-gainfully employed to countries with a high level of benefits. The growing claims to entitlements could lead to a situation in which the host countries were no longer able to maintain their levels of social security. In order to reduce the "attractiveness" of their welfare systems, they would curtail benefits. Other countries would then be obliged to do the same; an undesirable erosion of the social security systems in the EU would be the consequence (Sinn et al. 2003, chapters 2 and 4). Moreover, the call for harmonisation of the European systems of social security or for an internal European financial compensation scheme could become louder. The EU, however, would be incapable of responding at this times to these demands owing to a lack of jurisdiction and a lack of political readiness. These are also reasons why residence of inactive Union citizens in other member countries is subject to restrictive conditions.

The question arises, to what extent granting access of inactive Union citizens to the systems of welfare benefits of the host countries whilst at the same time making this access relatively difficult could give rise to a process of welfare migration from the Central and East European member countries (Sinn 2004).

\section{Welfare migration: Fundamental considerations and empirical evidence}

Generous welfare systems can influence the migration decisions of individuals in three respects. They can be the direct cause of migration; they can influence the choice of the host country; and they can prevent a return to the country of origin (Bauer 2002; Borjas 1999a). The following re-

marks focus above all on the decision to migrate, but the choice of the host country is also touched upon.

According to the economic theory of migration, the financial incentives to migrate depend on the extent to which the expected, discounted value of the improvement in net income exceeds the costs 
of migration (Borjas 1999b). ${ }^{5}$ In the case of employed persons, income is taken as consisting of wages $(W)$ and social security benefits $(S)$. The decision to migrate to country $\mathrm{H}$, the host country, from country $\mathrm{O}$, the country of origin, is economically justified when the present value of the stream of future income differentials exceeds the present discounted value of living expenses (LE) differentials plus the costs of migration $(M C)$ :

(1) $\int_{0}^{T} e^{-r t}\left\{W_{H}(t)-W_{O}(t)+S_{H}(t)-S_{O}(t)\right\} \mathrm{d} t>\int_{0}^{T} e^{-r t}\left\{L E_{H}(t)-L E_{O}(t)\right\} \mathrm{d} t+M C$.

$\mathrm{T}$ is the remaining life time and $\mathrm{r}$ the discount rate. The costs of migration include monetary costs such as the cost of travel to the host country, losses associated with the sale of assets in the country of origin and intangible costs such as the loss of social relationships. In the case of non-gainfully employed persons, whose income consists only of social security benefits, this condition is given by:

(2) $\int_{0}^{T} e^{-r t}\left\{S_{H}(t)-S_{O}(t)\right\} \mathrm{d} t>\int_{0}^{T} e^{-r t}\left\{L E_{H}(t)-L E_{O}(t)\right\} \mathrm{d} t+M C$.

There are no empirical studies of the effects of different standards of welfare benefits in the EU member countries on internal migration flows. Up till now, only studies on the influence of the generosity of welfare systems in the EU on the migratory decisions of immigrants from non-EU countries (willingness to migrate and choice of host country) have been carried out. Both Brücker et al. (2002), who have studied migration from a large number of non-EU countries, and De Giorgi and Pellizzari (2006), who have examined migration from the Central and East European countries before they became members of the EU, come to the conclusion that there is a weak, but significant connection between levels of welfare benefits and the decision to migrate. In interpreting this result it must be borne in mind that in comparison to migrants from other EU member countries, migrants from non-EU countries are subject to extensive legal restrictions with respect to their access to welfare benefits. Thus the conclusions obtained in these studies cannot be applied to migration within the EU. What is more, these studies did not confine themselves to non-gainfully employed persons, and it is the migration decisions of this group of persons which is at the centre of interest here.

For the United States of America, on the other hand, there is a fairly intensive empirical literature on the effects of different levels of social security in the individual states on migration within the USA. Theses studies limit themselves, however, not to the migration of non-gainfully employed persons. Meyer (2000) reviews these studies, adds some empirical research of his own and comes to the conclusion: "There is welfare induced migration, but it is modest in magnitude." Gelbach (2004) comes to the same conclusion. In interpreting these results one should bear in mind that in the USA owing to lack of language barriers the migration costs are in all likelihood lower than in Europe; on

5 Further factors influencing the decision to migrate are non-financial advantages; the relative chance of finding a job in the host country or at home, etc. 
the other hand, the differences in the level of welfare benefits between the individual US-American states are less than in the EU after its enlargement.

\section{Legal migration into welfare systems}

In the USA migration and access to welfare benefits are not restricted, whilst the Directive restricts access to welfare benefits in the host country. The migrating EU citizen must reside in the host country during a five years waiting period before he can claim welfare benefits. During this waiting period, the migrant must support himself out of his own resources and must pay health insurance premiums in the host country. In the case of non-gainfully employed persons, income from employment is not relevant, and this means that changing residence to another EU country requires that the migrant should dispose of sufficient financial assets.

Under the Directive, the migration incentives depend on the present discounted value of the income differential, which must exceed the costs of migration plus the present discounted value of living expenses differential. Non-gainfully employed persons will decide to migrate from $\mathrm{O}$ (land of origin) to $\mathrm{H}$ (host country) if the condition in (2) is fulfilled. The living expenses include normal expenditure for subsistence plus health insurance premiums.

Figure 1 describes the migration decision of a 60 year-old Pole who can claim old-age benefits in Poland upon reaching the age of 65. In the upper panel assets are entered on the vertical axis and time on the horizontal axis. Assets of the amount of $\mathrm{AB}$ are required in order to cover living expenses in Germany during the waiting period. ${ }^{6}$ In the case of a change of residence to Germany the migrant's assets will decline as shown by the curve AE. At the point in time $\mathrm{E}$ they will be entirely exhausted. At the end of the five year waiting period, our Pole is a pauper fulfilling the conditions for receiving welfare benefits just sufficient to cover his subsistence-level consumption. If, however, our person had remained in Poland, he would only have used up part of his initial assets, since the cost of living would be lower and premiums for health insurance would be less. Thus in the case of non-migration only $\mathrm{CD}$ of his assets would be used up; at the end of five years he would still own assets amounting to DE.

In the lower panel of Figure 1, the annual flows of income and costs that are relevant for the migration decision are shown graphically. They are converted at purchasing power parities (see section 6 for an explanation of these calculations). During the waiting period, total expenses associated with the stay in Germany amount to the area FHJM. This can be thought of as negative income. In Poland, on the other hand, the costs of living (including health insurance premiums) are lower (area FGJL). On balance, there is a difference in the expenditure for living expenses during the period of

6 In the grapical presentation, the costs of migration are not considered. 
Figure 1 Incentives to Migrate with Old-Age Benefit Entitlement in Country of Origin ${ }^{\text {a) }}$
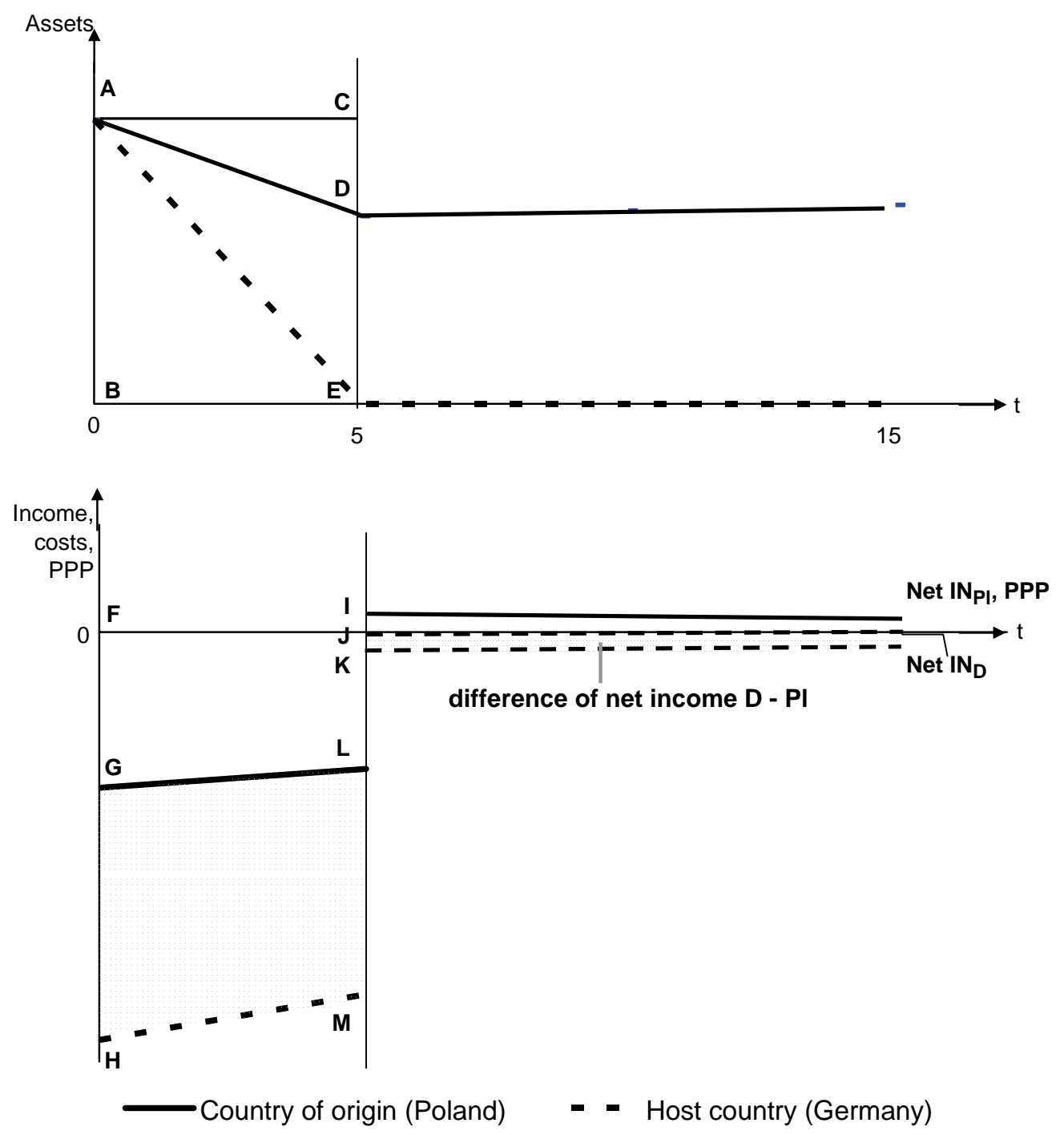

a) The incomes and costs in the graph are those for a single person.

Source: CESifo.

waiting amounting to GHLM. After the waiting period there is no surplus of net income that compensates for this difference. The net income (Net IN: social security benefits-living expenses) in Germany is zero whereas it is positive in Poland. Migration to Germany would not be financially attractive.

Figure 2 illustrates the migration decision of a 40 year-old foreigner, who has no claim to old-age benefits, but an entitlement to social assistance in the case of need. If this foreigner should migrate to Germany, he will have an entitlement to social assistance after five years. If he remains in Poland, however, he must exhaust his remaining assets amounting to DE and can claim welfare benefits only after fourteen (or fifteen) years. 
Figure 2 Incentives to Migrate with Social Assistance Entitlement
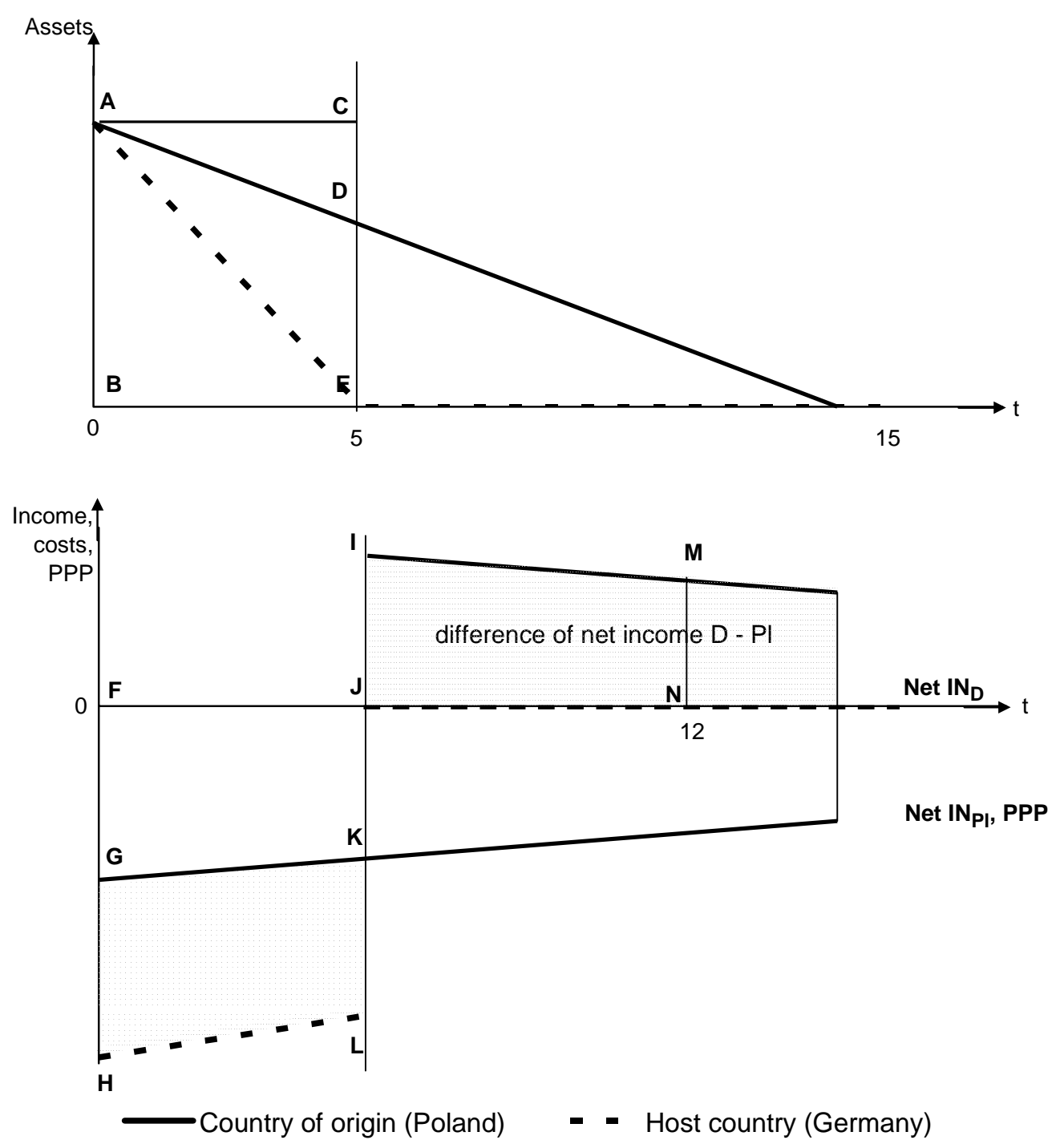

a) The incomes and costs in the graph are those for a single person.

Source: CESifo.

The migration decision depends on the income and costs streams depicted in the lower panel of Figure 2. During the waiting period, negative income in the form of living costs is incurred amounting to FHJL in Germany. In Poland these costs come to FGJK. The difference of living expenses is GHKL. Remaining assets must be liquidated to cover living costs and health insurance premiums before one can claim social assistance. The initial portfolio of assets is liquidated sooner in Germany. Starting at the end of five years, the immigrant is entitled to welfare benefits which are as high as his living expenses. His net income becomes zero. In Poland, he would go on experiencing negative income. This disparity of access to welfare benefits has the consequence that migration incentives get positive relatively early. This is the case as soon as the area IJMN exceeds the area GHKL. The difference of net income becomes greater than the difference between the living expenses incurred in Germany as compared to these expenses in Poland during the waiting period. 


\section{The calculations underlying the case studies presented in section 5}

In section 5 migration scenarios have been presented which are based on calculations that are as realistic as possible. They are based on 2005 values, which we assume will be valid also in the future. The 2005 values have only been adjusted by an inflation rate of 1.5 percent. We imagine a 60 year-old Pole who is entitled, in Poland, to old-age benefits upon reaching the age of 65. The decision to migrate requires that he has adequate monetary resources, for he must be able to cover his living expenses in Germany during the first five years out of his own resources. A socio-culturally defined subsistence minimum must be met at all times. In Germany this is defined by the statutory rate for social assistance including subsidies for housing and heating costs of $€ 672$ per month for a single person and $€ 1,047$ for a couple without children as of July 2005 . Moreover, he has private health insurance with a monthly premium of $€ 600$ for a man or $€ 620$ for a woman. Given these hypotheses, a single person would require an initial asset portfolio of $€ 71,876$; for a couple without children, the amount required would be $€ 128,100$ (see Table 1). The table shows present values of net incomes. The expenditure streams have been discounted by a nominal interest rate of 4.5 percent (real interest rate 3.0 percent, inflation rate 1.5 percent).

Table 1 Initial assets needed to change residence from Poland (PI) to Germany (D), in €

Case: $\quad 60$ year-old non-gainfully employed Pole with a claim to old-age benefits at age 65

Year 2005 present values

\begin{tabular}{|c|c|c|c|}
\hline & & Single person & $\begin{array}{l}\text { Couple, } \\
\text { no children }\end{array}$ \\
\hline \multicolumn{4}{|c|}{ Expenditure during the five year waiting period (year 1 to year 5) } \\
\hline & Living expenses in $\mathrm{D}^{\text {a) }}$ & 37972 & 59162 \\
\hline & Health insurance premiums in $\mathrm{D}^{\mathrm{b})}$ & 33904 & 68938 \\
\hline & Living expenses in $\mathrm{Pl}^{\mathrm{c})}$ & 19900 & 31008 \\
\hline & Health insurance premiums in $\mathrm{Pl}^{\mathrm{d}}$ ) & 3918 & 7836 \\
\hline & Required initial assets: $(1)+(2)$ & 71876 & 128100 \\
\hline & Assets remaining in D: (5) - (1) - (2) & 0 & 0 \\
\hline (7) & Assets remaining in $\mathrm{Pl}:(5)$ - (3) - (4) & 48058 & 89256 \\
\hline \multicolumn{4}{|c|}{$\begin{array}{l}\text { a) Assumption: The standard of living corresponds to a socio-culturally defined existence minimum. In D this } \\
\text { is defined by the statutory rate for social assistance including subsidies for housing and heating costs as of } \\
\text { July } 2005 \text {. }\end{array}$} \\
\hline \multicolumn{4}{|c|}{$\begin{array}{l}\text { b) Private health insurance: } 60 \text { year-old man: } € 600,60 \text { year-old woman: } € 620 \text { (anonymous data supplied by } \\
\text { financial services firm AWD). }\end{array}$} \\
\hline \multicolumn{4}{|c|}{$\begin{array}{l}\text { c) The cost of living in } \mathrm{Pl} \text { is calculated on the basis of the cost of living in } \mathrm{D} \text { (subsistence minimum) adjusted } \\
\text { by a conversion factor based on purchasing power parities. The conversion factor is } 1.9081 \text { (Feb. 2006, the } \\
\text { source is OECD). }\end{array}$} \\
\hline \multicolumn{4}{|c|}{$\begin{array}{l}\text { d) Rate of contribution of } 11.2 \text { percent applied to average income of } 30,000 \text { złoty and converted to euro } \\
\text { (Source: EU MISSOC 2005; OECD Taxing Wages 2004/05, p. 332). }\end{array}$} \\
\hline
\end{tabular}

Source: CESifo. 
In Germany, the initial portfolio of assets will be entirely liquidated during the waiting period. This removes an obstacle to claiming social assistance, which is conditioned on need. In Poland, on the other hand, some assets remain at the end of the waiting period, since the cost of living and the cost of health insurance is lower than in Germany. The portfolio will contain $€ 48,058$ for a single person or $€ 89,256$ for a couple without children at the end of the waiting period.

Table 2 Financial incentives for changing residence from Poland (Pl) to Germany (D), in $€$

Case: $\quad 60$ year-old non-gainfully employed Pole with a claim to old-age benefits at age 65

Year 2005 present values

\begin{tabular}{|c|c|c|c|}
\hline & & Single person & $\begin{array}{l}\text { Couple, } \\
\text { no children }\end{array}$ \\
\hline \multicolumn{4}{|c|}{ Expenditure during the five year waiting period (year 1 to year 5) } \\
\hline$(1)$ & Living expenses in $\mathrm{D}^{\text {a) }}$ & 37972 & 59162 \\
\hline & Health insurance premiums in $\mathrm{D}^{\mathrm{b})}$ & 33904 & 68938 \\
\hline & Living expenses in $\mathrm{Pl}, \mathrm{PPP}^{\mathrm{c}}$ & 19900 & 31008 \\
\hline & Health insurance premiums in $\mathrm{Pl}, \mathrm{PPP}{ }^{\mathrm{d})}$ & 7478 & 14951 \\
\hline & Difference in living expenses D - Pl (1) + (2)- (3) - (4) & 44499 & 82141 \\
\hline \multicolumn{4}{|c|}{ Income starting at the age of 65 (year 6 to year 15) } \\
\hline & Welfare benefits in $\mathrm{D}^{\text {a) }}$ & 60610 & 94432 \\
\hline & Living expenses in $\mathrm{D}^{\text {a) }}$ & 60610 & 94432 \\
\hline & Old-age benefits in $\mathrm{Pl}, \mathrm{PPP}{ }^{\mathrm{e})}$ & 37520 & 37520 \\
\hline & Living expenses in $\mathrm{Pl}, \mathrm{PPP}^{\mathrm{f}}$ ) & 31763 & 49493 \\
\hline (10) & Difference in net income D-P1 (6-7) - (8-9) & -5757 & 11973 \\
\hline \multicolumn{4}{|c|}{$\begin{array}{l}\text { a) - c) See Table } 1 \text {. } \\
\text { d) See Table 1, conversion based on PPP. } \\
\text { e) Net old age benefits }=0.516 \times \text { average net wages }=€ 2,616 \text {; } € 2,616 \times 1.9081=€ 4,992 \text {. } \\
\text { (Source: OECD, Pensions at a Glance, } 2005 \text { Edition, p. 163; OECD, Taxing Wages 2004-2005, } \\
\text { p. 332). Contributions to health insurance have been deducted. }\end{array}$} \\
\hline \multicolumn{4}{|c|}{ f) Without health insurance premiums. } \\
\hline
\end{tabular}

Source: CESifo.

Apart from the possession of adequate assets, migration from Poland to Germany also depends on the expected gain in income that must be sufficient to cover the difference in living expenses as well as the direct migration costs (which are neglected in these calculations). In making this calculation, the streams of net income in Poland and Germany must be made comparable, i.e. the difference in the cost of living in the two countries must be taken into account. This has been done here by converting the stream of net income in Poland with the purchasing power parity of the euro and the złoty. Table 2 shows the present values of net incomes. Social assistance which could be claimed in Germany after the waiting period is compared to the old-age benefits which an average employee receives in Poland and the living expenses in the two countries: The comparison shows that starting at age 65, a single person in Germany can expect within the next ten years a net income that is below his net income in Poland by $€ 5,757$. For a couple without children net income in Ger- 
many exceeds the corresponding figure in Poland by $€ 11,973$ which is however not enough to compensate for the difference in living expenses during the waiting period. In both cases, changing residence from Poland to Germany is not financially attractive.

Different results are obtained if one assumes a 40 year-old, non-gainfully employed Pole who in the foreseeable future has no expectations of old-age benefits and in case of need has only an entitlement to basic subsistence as defined in the Polish welfare system. The amounts of assets required initially for migration to Germany are lower than in the previous case, since the monthly premiums for health insurance for a forty year old man are only $€ 310$, for a woman of the same age $€ 390$. Hence, a single person needs $€ 55,489$ at the beginning of his stay, a couple without children would require $€ 98,716$. In Germany, these assets would be entirely exhausted at the end of the five-year waiting period, whilst in Poland, the single person would still have $€ 31,672$ at the end of the period and the childless couple would retain $€ 59,872$ (see Table 3).

Table 3 Initial assets needed to change residence from Poland (PI) to Germany (D), in $€$

Case: $\quad 40$ year-old non-gainfully employed Pole with a claim to social assistance in case of need

Year 2005 present values

\begin{tabular}{|c|c|c|c|}
\hline & & Single person & $\begin{array}{l}\text { Couple, } \\
\text { no children }\end{array}$ \\
\hline \multicolumn{4}{|c|}{ Expenditure during the five year waiting period (year 1 to year 5 ) } \\
\hline & Living expenses in $\mathrm{D}^{\text {a) }}$ & 37972 & 59162 \\
\hline & Health insurance premiums in $\mathrm{D}^{\mathrm{b})}$ & 17517 & 39554 \\
\hline & Living expenses in $\mathrm{Pl}^{\mathrm{c}}{ }^{\mathrm{c}}$ & 19900 & 31008 \\
\hline & Health insurance premiums in $\mathrm{Pl}^{\mathrm{d})}$ & 3918 & 7836 \\
\hline & Required initial assets: $(1)+(2)$ & 55489 & 98716 \\
\hline & Assets remaining in D: (5) - (1) - (2) & 0 & 0 \\
\hline (7) & Assets remaining in $\mathrm{Pl}$ : (5) - (3) - (4) & 31672 & 59872 \\
\hline \multicolumn{4}{|c|}{ (8) Assets: value of zero attained } \\
\hline & in Germany & in year 5 & in year 5 \\
\hline & in Poland & in year 14 & in year 15 \\
\hline \multicolumn{4}{|c|}{$\begin{array}{l}\text { a) See Table } 1 \text {. } \\
\text { b) Private health insurance: } 40 \text { year-old man: } € 310,40 \text { year-old woman: } € 390 \text { a month (anonymous data } \\
\text { supplied by financial services firm AWD). } \\
\text { c)-d) See Table } 1 .\end{array}$} \\
\hline
\end{tabular}

Source: CESifo.

In comparing the net income improvement which can be expected after the waiting period is over with the difference in the living expenses during the waiting period, it must be borne in mind that if our citizen remains in Poland, he will earn no income. Expenditure for necessities and health insurance premiums must be covered by the liquidation of assets. This reduction in assets is considered here to be negative income. As net income in Germany is zero, the difference in net income between residence in Germany and staying in Poland is positive. In the case of a single person, in year 
12 the present value of the differences in net income amounts to $€ 31.957$ (= area IJMN in Figure 2) and exceeds the present value of the differences in living expenses (= area GHKL in Figure 2). In the case of a couple without children, this surplus of net income differences over living expenses differences is also reached in the $12^{\text {th }}$ year, in which the net income differences sum to $€ 53,645$, whilst living expense differences total to $€ 52,757$. As long as the citizens contemplating migration expect to live beyond the age of 52 and expect to receive social assistance or unemployment benefit II in Germany, then migration from Poland to Germany would be attractive. If the direct costs of migration are included in the calculation, then the conclusion remains the same, but the length of time one must expect to live increases.

Table 4 Financial incentives for changing residence from Poland (PI) to Germany (D), in $€$

Case: $\quad 40$ year-old non-gainfully employed Pole with a claim to social assistance in case of need

Year 2005 present values

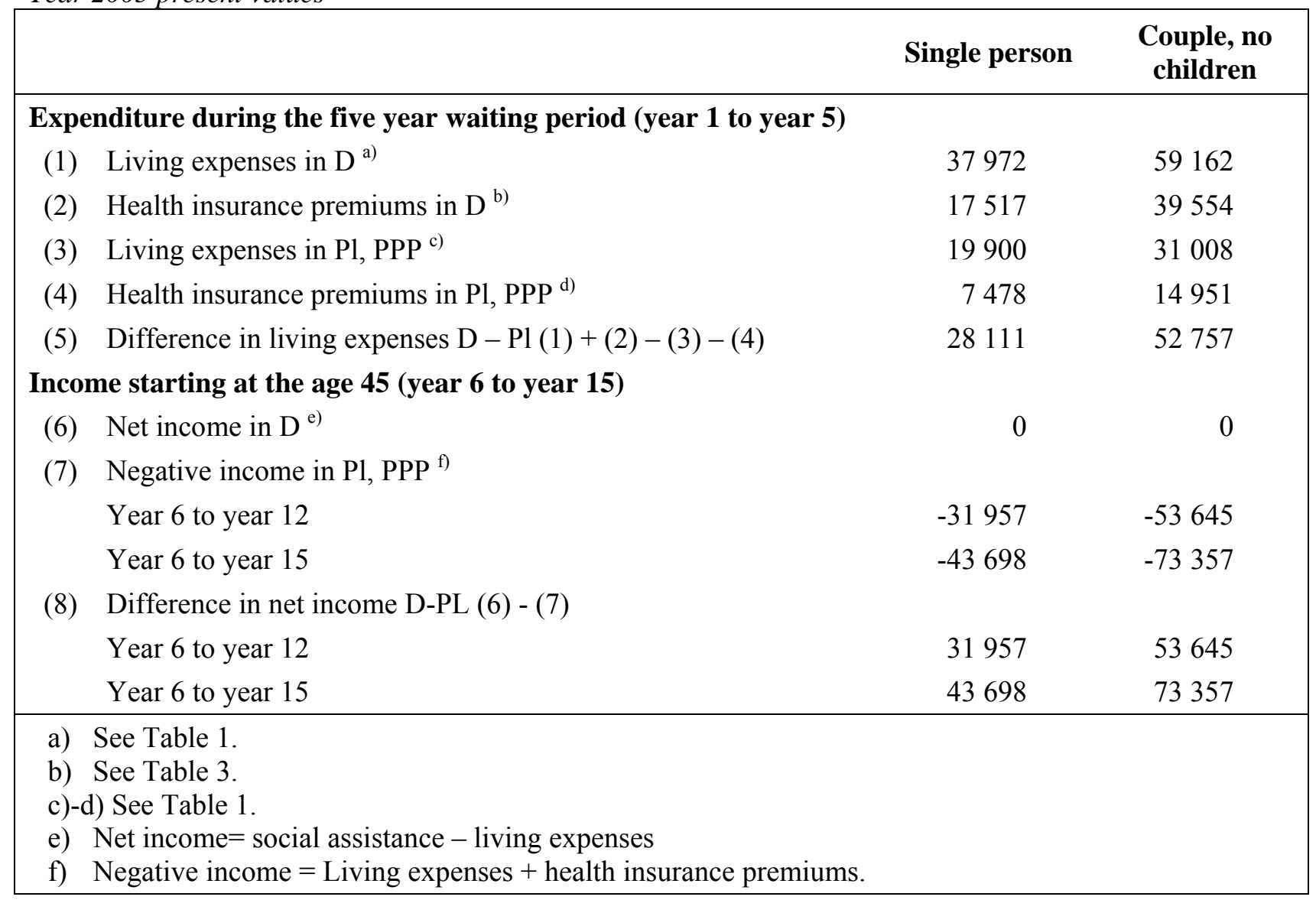

Source: CESifo. 


\section{Illegal migration into the welfare systems}

The conditions linked to the right of permanent residence can be circumvented only in part. Establishing residence in the host country and taking out health insurance are absolutely indispensable requirements. With a view to reducing the costs of living during the waiting period, a Union citizen could continue to live in his land of origin, whilst giving the registration office of the "host" country pro forma an address of a relative or a friend. This manoeuvre would, however, only be practicable if the travel costs are not too high. It is in any case illegal and hence involves risks.

The Directive imposes the requirement that the migrant has adequate financial assets. If the Union citizen desirous of migrating has no assets, one can imagine that relatives or friends might be willing to place the required sum at his disposal temporarily in order to show fulfilment of the requirements. Nonetheless, the migrant will as a rule have to cover his living expenses and health insurance premiums out of his own resources. If assets are not present, then the only way to do this is to work in the informal sector of the economy, which it goes without saying, is also illegal.

The incentives to migrate in the case of work in the informal sector of the host country depend on the gain in net income resulting from migration; in this respect the analysis is in principle not different from the case of legal migration of workers (see condition 1), but of course in the case of work in the informal sector, the risk of not finding an adequately remunerated job is greater. Figure 3 illustrates the migration decision. Initial assets amount to nil (not shown in the figure). During the waiting period, the Union citizen in Germany obtains wages from work in the informal sector which amount to living expenses and health insurance premiums so that his net income is zero. In Poland he receives wages from regular employment leading to a positive net income (area ABEF). After the waiting period is expired, the migrant in Germany can expect income from social assistance and from illegal work. In Poland, he goes on working regularly. At the point in time at which DEHI > $\mathrm{BCFG}$, migration becomes financially attractive.

In Table 5, the net income that could be obtained in Germany is compared to the net income that could be obtained in Poland. In Germany, the income from illegal work must cover at least a socioculturally defined subsistence minimum (that is to say, must at least equal social assistance which is defined by such a standard); in addition, it must be sufficient to cover health insurance premiums. For a single person, $€ 55,489$ is sufficient to fulfil this requirement during the waiting period. In order to earn this amount, if our immigrant works 150 hours a month, a hourly wage of $€ 6.55$ would suffice; if only 100 hours are worked, the hourly wage would have to be at least $€ 9.83$. The corresponding figures for a couple without children are €98,716. If they together work 250 hours a month, an hourly wage of $€ 6.99$ would suffice; if they only work 167 hours a month, then the hourly wage would have to be at least $€ 10.46$. If one assumes that our immigrants would earn an average wage in Poland, then the difference in net income between Germany and Poland comes to $-€ 25,644$ for the single person and to $-€ 43,152$ for a couple without children. 


\section{Figure 3 Incentives to Migrate in the Case of Illegal Work ${ }^{\text {a) }}$ in the Host Country}

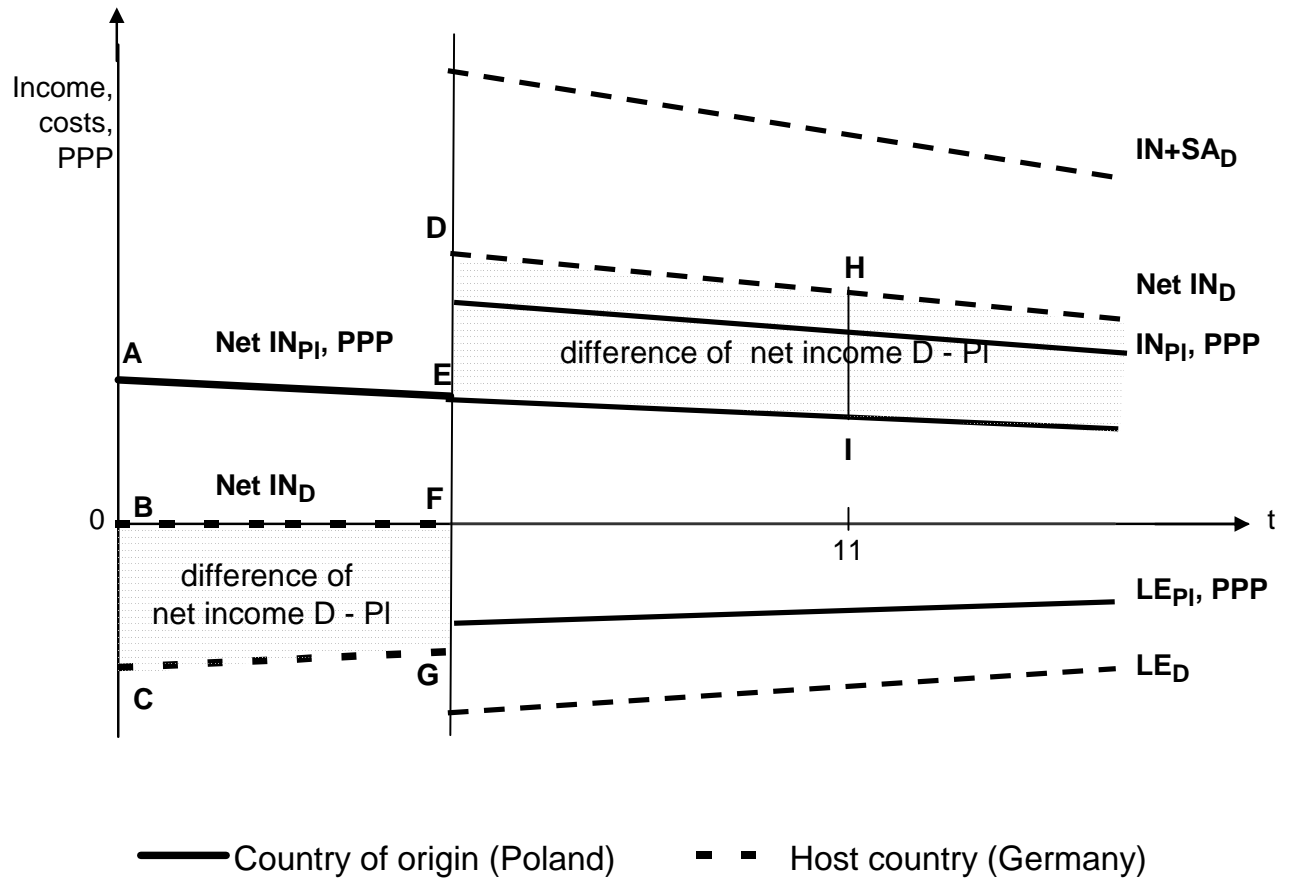

IN: Income; LE: Living expenses; Net IN: Net income (income-costs);

SA: Social assistance.

a) The incomes and costs in the graph are those for a single person.

Source: CESifo.

At the end of the waiting period, our immigrant to Germany can expect to receive social assistance or unemployment benefit II. This later form of welfare is given to persons deemed capable of employment. Since welfare benefits minus living expenses in Germany are, on purchasing power terms, less than the net income of an average Polish employee, migration to Germany would not be financially attractive, unless the migrant goes on working in the informal sector after the waiting period is expired. In the latter case the present value of the net income received in Germany between year 6 and year 15 will be $€ 47,637$ more than in Poland for a single person and $€ 88,690$ more for a childless couple. For a stay in Germany of eleven, respectively ten years, and abstracting from migration costs, changing residence to Germany is financially attractive. However, in the cases examined here one must bear in mind the risk of not finding work in the informal sector, or the risk of being discovered in an illegal job. 
Table 5 Financial incentives for changing residence from Poland (Pl) to Germany (D), in $€$

Case: $\quad 40$ year-old Pole without assets; expenses in Germany covered by work in informal sector

Year 2005 present values

\begin{tabular}{|c|c|c|c|}
\hline & & Single person & Couple, no children \\
\hline \multicolumn{4}{|c|}{ Net income during the waiting period (year 1 to year 5 ) } \\
\hline & $\begin{array}{l}\text { Income amounting to living expenses and health in- } \\
\text { surance premiums in } \mathrm{D}^{\text {a) }}\end{array}$ & 55489 & 98716 \\
\hline (2) & Living expenses and health insurance premiums in D & 55489 & 98716 \\
\hline & Net income in D (1) - (2) & 0 & 0 \\
\hline & Income of an average worker in $\mathrm{Pl}, \mathrm{PPP}^{\mathrm{b})}$ & 45544 & 74174 \\
\hline & Living expenses in Pl, PPP & 19900 & 31022 \\
\hline & Net income in Pl, PPP (4) - (5) & 25644 & 43152 \\
\hline & Difference in net income D-Pl (3) - (6) & -25644 & -43152 \\
\hline \multicolumn{4}{|c|}{ Net income starting in year 6 (year 6 to year 15) } \\
\hline & Social assistance or unemployment benefit II in D & 60610 & 94432 \\
\hline & Income from illegal work in $\mathrm{D}$ & 88569 & 157567 \\
\hline$(10)$ & Living expenses in D & 60610 & 94432 \\
\hline (11) & Net income in $\mathrm{D}(8)+(9)-(10)$ & 88569 & 157567 \\
\hline (12) & Net income in $\mathrm{Pl}, \mathrm{PPP}$ & 40932 & 68877 \\
\hline (13) & Difference in net income D-Pl (11) - (12) & 47637 & 88690 \\
\hline (14) & Financial incentive to migrate starting in year $\left.{ }^{d}\right)$ & 11 & 10 \\
\hline \multicolumn{4}{|c|}{$\begin{array}{l}\text { a) Assumption: earnings from illegal work are sufficient to cover a socio-culturally defined subsistence } \\
\text { minimum plus health insurance premiums. } \\
\text { b) Net income is calculated after deducting health insurance premiums. } \\
\text { c) Social assistance in Germany includes free health insurance; hence, income from illegal work no } \\
\text { longer must be used, as is the case during the waiting period, for health insurance premiums. } \\
\text { d) The year in which the negative income difference during the waiting period (line 7) is fully compensated } \\
\text { for by the income surplus. }\end{array}$} \\
\hline
\end{tabular}

Source: CESifo.

Our Union citizen, who is assumed to be fit for employment, has a further option: he can continue in Poland in regular employment until the end of 2011, when free movement of workers will begin to apply to Germany as well. Beginning in 2012, he can seek regular employment in Germany. In this case the potential migrant will have a higher net income during the "waiting period" compared to going in 2006 to Germany. On the other hand his net income in Germany from 2012 onwards might be lower than net income from welfare and work in the informal sector. It would, however, have the advantage that obtaining welfare benefits fraudulently and engaging in illegal work in the informal sector would be avoided.

A further alternative is to migrate in 2007 into one of the eight EU countries which impose no restrictions on migration from other EU countries. Great Britain would, for example, be an attractive 
destination. If our Polish citizen managed to find employment at $2 / 3$ of the average yearly net income of employees in that country, i.e. at $€ 20,373$ p. a. ${ }^{7}$, than he would be much better off financially than the options discussed up till now, and would in this case also enjoy the advantages of legality.

\section{Summary and conclusions}

Since the beginning of the 1990s, the restrictions on the freedom of movement and choice of residence of EU citizens have been progressively lifted. The Directive which went into force in 2004 laid down new and more liberal rules for movement across borders and for taking up residence in another EU country. Access to welfare benefits in host countries was made easier, although it continued to be tied to certain requirements.

The question arises as to what extent these new regulations will provoke migration within the EU from the less developed countries to the more developed countries. Since the Directive was not implemented in the member countries until 2006 it is impossible to provide an answer to this question based on an ex-post analysis. Instead, calculations have been made of the financial incentives to migrate in a number of model cases. The countries studied were Poland as the country of origin of the migrants, and Germany as the host country. Since welfare benefits are more generous in Germany, migration into German welfare systems is to be expected. However, the rules and regulations in force impose a waiting period of five years which must first be bridged. This in turn means that an inactive Polish citizen seeking access to Germany's welfare systems must have at the beginning considerable financial assets. Only few Poles are able to fulfil this requirement. Then too, these persons must be prepared to liquidate these assets during the waiting period with a view to obtaining later welfare benefits in Germany. This is fraught with risks for the migrant, e.g. the risk that he will die during the waiting period, or that there might be a subsequent modification of the rules and regulations in his disfavour.

Apart from the possession of adequate assets there should be a surplus of net income arising from migration. To the extent that after the waiting period there is an entitlement to old-age benefits in Poland, then on a purchasing power parity basis, the net income in Poland will exceed the net income to be expected in Germany: there is no financial incentive to migrate from Poland to Germany in such a case. If, however, the Polish citizen has to use up existing financial assets before he can put in a claim for social assistance - and this is in all likelihood the more general case - than there is indeed a financial incentive to migrate to Germany in order to take advantage of the more generous welfare benefits there.

If one considers persons who have no financial assets but who are capable of working, then the calculations show that migration is attractive assuming that they work in Germany in the informal sec-

7 OECD, Taxing Wages 2004-05, Paris, p. 200. 
tor; at the expiration of five years, they expect to also receive social assistance or unemployment benefit II. This option is, however, illegal and pursuing it involves considerable risks. For those capable of working it is more rewarding to seek employment in one of the EU countries that is open to migrants.

This analysis focuses on financial incentives. However, the social sphere, language and cultural differences between the countries under consideration are also important for the decision to migrate. Then too, individual factors such as life expectancy, life plan and the evaluation of risk influence the individual Union citizen's migration decision.

A number of years will have to pass before the effects on the migration of non-gainfully employed persons into the welfare systems of individual EU member countries arising from the Directive will be known empirically. But it is already possible to say that in enacting the Directive the European lawmakers have incurred a considerable risk. For access of non-gainfully employed to welfare systems has not been cut off, but only made relatively difficult by imposing certain conditions. In view of the still rudimentary nature of the financial compensation framework within the EU, it is entirely possible that the freedom of movement that has been accorded will impose excessive demands on the solidarity of Union citizens in the host countries. 


\section{References}

Bauer, T. K. (2002), "Migration, Sozialstaat und Zuwanderungspolitik", Vierteljahreshefte zur Wirtschaftsforschung 71 (2), 249-271.

Borjas, G. J. (1999a), “Immigration and Welfare Magnets", Journal of Labor Economics 17 (4), 607-637.

Borjas, G. J. (1999b), “The Economic Analysis of Immigration”, in O. Ashenfelter and D. Card, eds., Handbook of Labor Economics, Vol. 3 A, Amsterdam, 1697-1760.

Brücker, H., G. S. Epstein, B. McCormick, G. Saint-Paul, A. Venturini and K. F. Zimmermann (2002), "Managing Migration in the European Welfare State", in T. Boeri, G. Hanson and B. McCormick, eds., Immigration Policy and the Welfare State, Oxford University Press, Oxford, $1-167$.

Bundesministerium des Inneren, Projektgruppe Zuwanderung (2004), Vorläufige Anwendungshinweise des Bundesministeriums des Inneren zum Aufenthaltsgesetz und zum Freizügigkeitsgesetz/EU (Version: 22. Dezember 2004).

CESifo, EEAG (2004), Report on the European Economy, Munich.

Gelbach, J. B. (2004), "Migration, the Life Cycle, and State Benefits", Journal of Political Economy 112 (5), 1091-1130.

De Giorgi, G. and M. Pellizzari (2006), "Welfare Migration in Europe and the Cost of a Harmonised Social Assistance”, IZA Discussion Paper 2094.

Groß, H. (2006), "Die Umsetzung der EU-Freizügigkeitsrichtlinie im deutschen Recht”, ZAR 2, 6164.

Hailbronner, K. (2005), "Union Citizenship and Access to Social Benefits", Common Market Law Review 42, 1245-1267.

Hailbronner, K. (2006), "Union Citizenship and Social Rights", in J.-Y. Carlier and E. Guild, eds., The Future of Free Movement of Persons in the EU, Bruyland, Bruxelles, 65-78.

Meyer, B. D. (2000), "Do the Poor Move to Receive Higher Welfare Benefits?”, Mimeo, Northwestern University, Chicago.

Niemann, I. (2004), “Von der Unionsbürgerschaft zur Sozialunion?”, EuR, Heft 6, 946-953.

Sander, F. (2005), "Die Unionsbürgerschaft als Türöffner zu mitgliedstaatlichen Sozialversicherungssystemen? - Überlegungen anlässlich des Trojani-Urteils des EuGH”, Deutsches Verwaltungsblatt (DVBL), 1014-1022.

Schierup, C.-U., P. Hansen and S. Castles (2006), Migration, Citizenship, and the European Welfare State, A European Dilemma, Oxford University Press, Oxford. 
Sinn, H.-W., G. Flaig, M. Werding, S. Munz, H. Hofmann and N. Düll (2003), EU Enlargement and Labour Mobility - Consequences for Labour Markets and Redistribution by the State in Germany, CESifo Research Reports 2, ifo Institute for Economic Research, Munich.

Sinn, H.-W. (2004), "Freizügigkeitsrichtlinie: Freifahrt in den Sozialstaat”, ifo Standpunkt 53.

Tomuschat, C. (2000), “'Radical' Equality under Article 12 (ex 6) EC?”, Common Market Law Review $37,449-457$. 


\section{CESifo Working Paper Series}

(for full list see www.cesifo-group.de)

1868 Thomas Eichner and Marco Runkel, Corporate Income Taxation of Multinationals and Unemployment, December 2006

1869 Balázs Égert, Central Bank Interventions, Communication and Interest Rate Policy in Emerging European Economies, December 2006

1870 John Geweke, Joel Horowitz and M. Hashem Pesaran, Econometrics: A Bird's Eye View, December 2006

1871 Hans Jarle Kind, Marko Koethenbuerger and Guttorm Schjelderup, Taxation in TwoSided Markets, December 2006

1872 Hans Gersbach and Bernhard Pachl, Cake Division by Majority Decision, December 2006

1873 Gunther Schnabl, The Evolution of the East Asian Currency Baskets - Still Undisclosed and Changing, December 2006

1874 Horst Raff and Michael J. Ryan, Firm-Specific Characteristics and the Timing of Foreign Direct Investment Projects, December 2006

1875 Jukka Pirttilä and Håkan Selin, How Successful is the Dual Income Tax? Evidence from the Finnish Tax Reform of 1993, December 2006

1876 Agnieszka Stążka, Sources of Real Exchange Rate Fluctuations in Central and Eastern Europe - Temporary or Permanent?, December 2006

1877 Xavier Calsamiglia, Teresa Garcia-Milà and Therese J. McGuire, Why do Differences in the Degree of Fiscal Decentralization Endure?, December 2006

1878 Natacha Gilson, How to be Well Shod to Absorb Shocks? Shock Synchronization and Joining the Euro Zone, December 2006

1879 Scott Alan Carson, Modern Health Standards for Peoples of the Past: Biological Conditions by Race in the American South, 1873 - 1919, December 2006

1880 Peter Huber, Michael Pfaffermayr and Yvonne Wolfmayr, Are there Border Effects in the EU Wage Function?, December 2006

1881 Harry Flam and Håkan Nordström, Euro Effects on the Intensive and Extensive Margins of Trade, December 2006

1882 Panu Poutvaara and Mikael Priks, Hooliganism in the Shadow of the 9/11 Terrorist Attack and the Tsunami: Do Police Reduce Group Violence?, December 2006 
1883 Ruud A. de Mooij and Gaëtan Nicodème, Corporate Tax Policy, Entrepreneurship and Incorporation in the EU, December 2006

1884 Johannes Becker and Clemens Fuest, Corporate Tax Policy and International Mergers and Acquisitions - Is the Tax Exemption System Superior?, January 2007

1885 Momi Dahan and Udi Nisan, The Effect of Benefits Level on Take-up Rates: Evidence from a Natural Experiment, January 2007

1886 José García-Solanes, Francisco I. Sancho-Portero and Fernando Torrejón-Flores, Beyond the Salassa-Samuelson Effect in some New Member States of the European Union, January 2007

1887 Peter Egger, Wolfgang Eggert and Hannes Winner, Saving Taxes Through Foreign Plant Ownership, January 2007

1888 Timothy J. Goodspeed and Andrew Haughwout, On the Optimal Design of Disaster Insurance in a Federation, January 2007

1889 Wim Groot, Henriëtte Maassen van den Brink and Bernard van Praag, The Compensating Income Variation of Social Capital, January 2007

1890 Bas Jacobs, Ruud A. de Mooij and Kees Folmer, Analyzing a Flat Income Tax in the Netherlands, January 2007

1891 Hans Jarle Kind, Guttorm Schjelderup and Frank Stähler, Newspapers and Advertising: The Effects of Ad-Valorem Taxation under Duopoly, January 2007

1892 Erkki Koskela and Rune Stenbacka, Equilibrium Unemployment with Outsourcing under Labour Market Imperfections, January 2007

1893 Maarten Bosker, Steven Brakman, Harry Garretsen, Herman de Jong and Marc Schramm, The Development of Cities in Italy 1300 - 1861, January 2007

1894 Michel Beine, Oscar Bernal, Jean-Yves Gnabo and Christelle Lecourt, Intervention Policy of the BoJ: A Unified Approach, January 2007

1895 Robert S. Chirinko and Daniel J. Wilson, State Investment Tax Incentives: A Zero-Sum Game?, January 2007

1896 Theo S. Eicher and Oliver Roehn, Sources of the German Productivity Demise Tracing the Effects of Industry-Level ICT Investment, January 2007

1897 Helge Berger, Volker Nitsch and Tonny Lybek, Central Bank Boards around the World: Why does Membership Size Differ?, January 2007

1898 Gabriel Felbermayr and Wilhelm Kohler, Does WTO Membership Make a Difference at the Extensive Margin of World Trade?, January 2007 
1899 Benno Torgler and Friedrich Schneider, The Impact of Tax Morale and Institutional Quality on the Shadow Economy, January 2007

1900 Tomer Blumkin and Efraim Sadka, On the Desirability of Taxing Charitable Contributions, January 2007

1901 Frederick van der Ploeg and Reinhilde Veugelers, Higher Education Reform and the Renewed Lisbon Strategy: Role of Member States and the European Commission, January 2007

1902 John Lewis, Hitting and Hoping? Meeting the Exchange Rate and Inflation Criteria during a Period of Nominal Convergence, January 2007

1903 Torben M. Andersen, The Scandinavian Model - Prospects and Challenges, January 2007

1904 Stephane Dees, Sean Holly, M. Hashem Pesaran and L. Vanessa Smith, Long Run Macroeconomic Relations in the Global Economy, January 2007

1905 Richard Jong-A-Pin and Jakob De Haan, Political Regime Change, Economic Reform and Growth Accelerations, January 2007

1906 Sascha O. Becker and Peter H. Egger, Endogenous Product versus Process Innovation and a Firm's Propensity to Export, February 2007

1907 Theo S. Eicher, Chris Papageorgiou and Oliver Roehn, Unraveling the Fortunates of the Fortunate: An Iterative Bayesian Model Averaging (IBMA) Approach, February 2007

1908 Liliana E. Pezzin, Robert A. Pollak and Barbara S. Schone, Efficiency in Family Bargaining: Living Arrangements and Caregiving Decisions of Adult Children and Disabled Elderly Parents, February 2007

1909 Christian Keuschnigg and Soren Bo Nielsen, Self-Selection and Advice in Venture Capital Finance, February 2007

1910 Rune Jansen Hagen and Gaute Torsvik, Irreversible Investments, Dynamic Inconsistency and Policy Convergence, February 2007

1911 Eric A. Hanushek and Ludger Woessmann, The Role of School Improvement in Economic Development, February 2007

1912 Bernard M. S. van Praag, Perspectives from the Happiness Literature and the Role of New Instruments for Policy Analysis, February 2007

1913 Volker Grossmann and Thomas M. Steger, Growth, Development, and Technological Change, February 2007

1914 Margarita Katsimi and Thomas Moutos, Human Capital and the Feldstein-Horioka Puzzle, February 2007 
1915 Oliver Roehn, Theo S. Eicher and Thomas Strobel, The Ifo Industry Growth Accounting Database, February 2007

1916 Ian Babetskii, Aggregate Wage Flexibility in Selected New EU Member States, February 2007

1917 Burkhard Heer, Alfred Maussner and Paul D. McNelis, The Money-Age Distribution: Empirical Facts and Limited Monetary Models, February 2007

1918 Yin-Wong Cheung, Menzie D. Chinn and Eijii Fujii, The Overvaluation of Renminbi Undervaluation, February 2007

1919 Jim Malley, Apostolis Philippopoulos and Ulrich Woitek, To React or Not? Fiscal Policy, Volatility and Welfare in the EU-3, February 2007

1920 Mattias Polborn, Competing for Recognition through Public Good Provision, February 2007

1921 Lars P. Feld and Benno Torgler, Tax Morale after the Reunification of Germany: Results from a Quasi-Natural Experiment, February 2007

1922 Robert S. Chirinko and Huntley Schaller, Fundamentals, Misvaluation, and Investment: The Real Story, February 2007

1923 Benno Torgler and Friedrich Schneider, Shadow Economy, Tax Morale, Governance and Institutional Quality: A Panel Analysis, February 2007

1924 Adrian Pagan and M. Hashem Pesaran, On Econometric Analysis of Structural Systems with Permanent and Transitory Shocks and Exogenous Variables, February 2007

1925 Hans-Werner Sinn, The Welfare State and the Forces of Globalization, February 2007

1926 Michael Smart, Raising Taxes through Equalization, February 2007

1927 Øystein Foros, Kåre P. Hagen and Hans Jarle Kind, Price-Dependent Profit Sharing as an Escape from the Bertrand Paradox, February 2007

1928 Balázs Égert, Kirsten Lommatzsch and Amina Lahrèche-Révil, Real Exchange Rates in Small Open OECD and Transition Economies: Comparing Apples with Oranges?, February 2007

1929 Aleksander Berentsen and Cyril Monnet, Monetary Policy in a Channel System, February 2007

1930 Wolfgang Ochel, The Free Movement of Inactive Citizens in the EU - A Challenge for the European Welfare State?, February 2007 